Journal of Teacher Education for Sustainability, vol. 22, no. 1, pp. 98-110, 2020

\title{
Classroom Action Research-based Instruction: The Sustainable Teacher Professional Development Strategy
}

\author{
Parinya Meesuk, Banleng Sramoon, and Angwara Wongrugsa \\ Rajamangala University of Technology Thanyaburi, Pathumthani, Thailand
}

\begin{abstract}
The purposes of this research were to study the current situation and to compare the consequences of the Child Development Centre teachers on classroom action researchbased instruction. The sample was 81 teachers of the Child Development Centre of the Local Administrative Organisation, derived from multi-stage random sampling. The instruments were the semi-structured interview form, and the measurement form of learning management outcomes, which the validity was between $0.80-1.00$ and reliability was 0.968 . The data were analysed by percentage, mean, standard deviation, content analysis and independent $\mathrm{t}$-test. The results showed that 1 ) most teachers conducted informal classroom research to solve children's behaviour problems and to increase the development of children. They usually utilised their research than others, but still not much. 2) the consequences of the classroom action research-based instruction were significantly higher than the standard requirement instruction at the .05 level of significance. The outstanding results have been discussed.
\end{abstract}

Key words: sustainable development, teacher development, professional development, classroom action research-based instruction, child development centre

\section{Introduction}

In developing countries, the educational providers are not only the Ministry of Education but also in other ministries such as Thailand the Ministry of Interior has been providing the education to people especially for the local rural area. As the foundation of the local government is decentralisation and democracy as is an organisation that allows people to participate in self-government. In Thailand and other countries, the local government organisation is also an agency that alleviates the burdens of the government, particularly in educational management.

Roles of the central and the regional government are changing from acting as an operator to be a supporter and provider of academic to the local (Munkong, 2019).

Royal Thai Government Gazette $(2017$, pp. 14, 74) designated that the decentralisation of authority to the locality has been stipulated in the constitution of Thailand. That 
is not just a decentralisation of governance, but the services and education management must decentralised to the people as well. The government must ensure that all children acquire quality education for twelve years, from pre-school to compulsory education, with free of charge. Moreover, ensuring the young children obtain the care and development before attending compulsory education to develop suitable physical, mental, discipline, emotion, social and intellect for the age.

Hence, that is the cause of the teachers of 191,171 Child Development Centres have to achieve knowledge and understanding of the goals of educational management and early childhood education curriculum. Moreover, they have been expected to analyse learners' potential and understand children individually. In addition, they must have the ability to organise student-centred learning, using technology to develop their own and learners' learning, assess and evaluate student by authentic assessment to develop the children's learning experiences to acquire their full potential. Further, they have to research to develop learners and themselves (Department of Local Administration, 2018, pp. 15-16).

The educational management of the Child Development Centre managed by the Ministry of Interior has different concepts and operations from the Ministry of Education. The teachers in the Child Development Centre are including carers. They have various roles and responsibilities, mainly in terms of teaching and learning management, child care, nutrition care, and cleanliness included. Huge responsibilities make they need to develop skills, expertise and appropriate learning management for children in contexts. The research for the development of learning or classroom action research is being an essential tool for coping their duties (Department of Local Administration, 2018). Because it can be used to solve problems that occur in the classroom according to each context, can be done quickly and directly, and enable teachers to develop their own learning management appropriately (Impedovo \& Ferreira-Meyers, 2019; Meesuk, Sramoon, \& Wongrugsa, 2019).

The current teacher professional development paradigm focuses on being productive for students and emphasising the development for teachers to gain knowledge and understanding and apply knowledge in curriculum development, teaching methods, measurement and evaluation (Petrovska, Sivevska, Popeska, \& Runcheva, 2018; Rutherford \& Lovorn, 2018). Moreover, encouraging teachers to develop themselves by self-practice and construct new knowledge and skills, not focusing on the traditional development model in which teachers are recipients of learning from others through external experts (Makovec, 2018; Sumaryanta, Mardapi, Sugiman, Herawan, 2019).

The studies have been found that the classroom action research is an effective solution as a bridge between theory and practice in teacher development in contexts (Bissonnette and Caprino, 2014; Ratnawati \& Idris, 2020). Accordance to the aim of education management that drives teachers to develop themselves by research for the development of learning or classroom action research as the teacher profession development (Meesuk, Sramoon, \& Wongrugsa, 2019). Teacher work is a profession that is recognised as a high-class profession that requires both science and art to perform. It is necessary to develop teachers' professions to a high standard. Even they are affiliated in which agency, the teacher professional must be developed equally and sustainably (Meesuk, 2016). Classroom action research is one of the important duties of teachers to do in parallel with learning management to develop themselves and students systemati- 
cally (Wongwanich, 2017). It is a sustainable professional development strategy for developing pedagogy, both theory and practice by using classroom action researchbased instruction. So, the classroom action research-based instruction has been implementing to develop the Child Development Centre teachers and student learning in Thailand for years. That is the source of research questions about how the Child Development Centre teacher managed classroom action research instruction? And how did the consequences occur?

In order to answer the research questions, the researcher determined research objectives were (1) to study the current situation of instructional management by classroom action research-based of the Child Development Centre teachers, and (2) to compare the consequences of the Child Development Centre teachers on classroom action research-based instruction.

\section{Literature Review}

\section{Classroom Action Research-based Instruction}

The professional development of teachers focuses on the ability to conduct classroom research to improve student learning and teaching in classes. That is the most meaningful and valuable research, classroom action research because it will expose the direction of teaching development. For the sustainability of education, teacher development is the main point. It is essential to encourage the teacher both knowledge, skills, and readiness of the teacher-as-learner (Mirke, Cakula, \& Tzivian, 2019). Therefore, classroom action research is one of the critical development methods of teaching and teacher professional (Kemmis \& McTaggart, 2000; Rutherford \& Lovorn, 2018; Impedovo \& FerreirsMeyers, 2019; Pipere, Veisson, \& Salīte, 2015; Fedosejeva, Boče, Romanova, Ivanova, \& Iliško, 2018; Heasly, Lindner, Iliško, \& Salīte, 2020).

Research-based learning concept is a learning and teaching process that encourages learners to learn from studying and discovering facts by themselves. It is the use of research processes or research findings as a basis of learning activities (Ratnawati \& Idris, 2020). The concept has been implemented to develop teachers of the child development centres throughout the country effectively (Wongwanich, 2017).

Classroom action research-based instruction defined as the teaching and learning process by emphasising that the research process has two related parts which are the research process and the research result. Therefore, the classroom action researchbased instruction can be both the use of the research processes and/or research results in teaching and learning. There are four forms of learning activities which can be divided (Akerson, Carter, Pongsanon, \& Nargund-Joshi, 2019; Giraud \& Saulpic, 2019; Meesuk, 2020; Pookeit, 2009; Rutherford \& Lovorn, 2018; Ratnawati \& Idris, 2020; Wongwanich, 2017) as shown in Figure 1. 


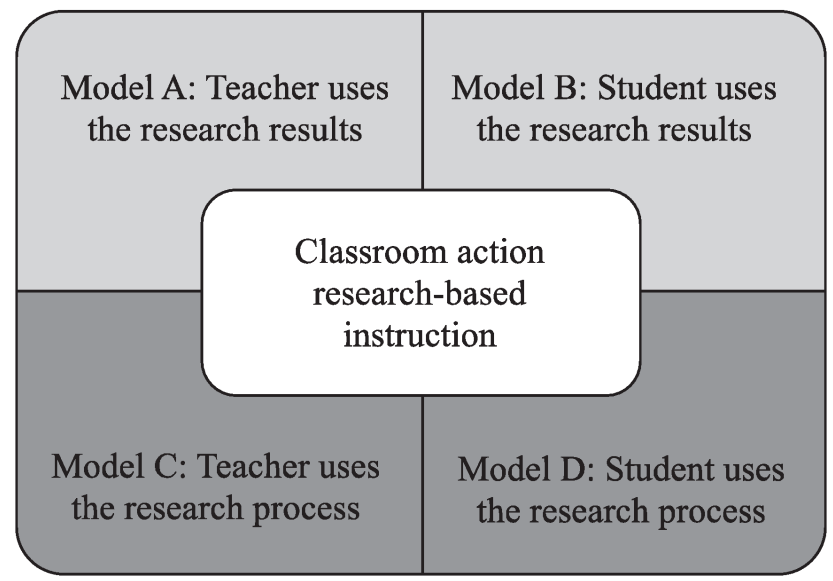

Figure 1. Types of classroom action research-based instruction

Model A: Teacher uses research results in teaching and learning. In which teachers use the research findings that are relevant to the content of the subject taught to expand the scope of knowledge, for learners to acquire up to date knowledge and familiar with research concepts.

Model B: Student uses research results in learning. The students are the one who interested in finding explanations, to support what they are studying and interested to search and study research related to the content that they are studying. The goal is to gain and expand knowledge in depth.

Model C: Teacher uses the research process in teaching and learning. The teacher is the user of the research process in all or any steps of the teaching and learning procedures, which is depending on the appropriateness of the content and age of the learner.

Model D: Student uses the research process in learning. The student is the user of the research process in all or any steps of learning. In which the teacher has a clear purpose that requires students to learn by doing or conducting research to construct knowledge or search for knowledge by themselves, which has six steps as follows:

Step 1 Identify research problems

Step 2 Hypothesising

Step 3 Hypothesis testing

Step 4 Data collection

Step 5 Data analysis

Step 6 Conclusions

According to the relevant ideas and concepts, researcher formed the research frame work as in Figure 2. 


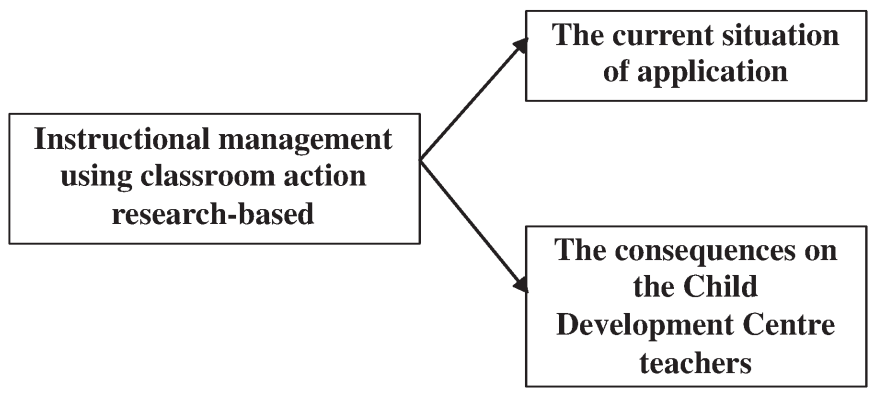

Figure 2. Research framework

\section{Methodology}

\section{Participants}

The research involved 81 teachers from the Child Development Centre of the Local Administrative Organisation, Thailand, divided into 40 participants in the experimental group and 41 participants in the control group. The subjects were asked to participate in research voluntarily. The three-stage random sampling was conducted, including

Stage I: Stratified random sampling, with the sampling unit as the region, consisting of 4 regions of Thailand. Then, randomised the region to be the representative by simple random sampling to gather samples in 2 regions.

Stage II: Province selection, the random unit was the province, the researcher randomly sampling a province in each region gathered from step I.

Stage III: Sample selection, the selection of Child Development Centre teachers to be a sample in the research. After the coordination to the provincial government for volunteer requests, there were 20 volunteers to join in the research project from each province, resulting was 40 samples for the experimental group. Then, the researcher asked for the volunteers to collect data on the learning management outcomes from the Child Development Centre teachers in the same province. They were assigned as the control group, resulting was 41 samples.

All participants in both the experimental and control groups were allowed by the supervisor and the head sector of the Child Development Centre and voluntarily participated in the project.

\section{Data Collection}

The research instruments were the semi-structured interview form, and the 20 -items of 5-score rating scale measurement form about learning management outcomes. The content validity of the instruments which the content validity, analysed by expert congruence index, was between 0.80-1.00 and reliability was 0.968.

The quasi-experimental design was conducted by pretest-posttest with control group design. Both groups of participants were asked to respond to the measurement form before and after the intervention of classroom action research-based instruction. They performed the classroom action research-based instruction within any model or integrated for a semester, as the experimental design shown in Figure 3. While the posttest period, 
the participants were asked to interview about what they did and how sustainable the method in professional developing.

\begin{tabular}{|c|c|c|l|}
\hline Pretest & Intervening & Posttest & Group \\
\hline $\mathrm{T} 1$ & $\mathrm{X}$ & $\mathrm{T} 2$ & Experiment \\
\hline $\mathrm{T} 1$ & $\sim \mathrm{X}$ & $\mathrm{T} 2$ & Control \\
\hline
\end{tabular}

Figure 3. Research design

\section{Data Analysis}

The data were analysed by frequency, percentage, mean, standard deviation, content analysis and independent t-test.

\section{Results}

\section{Current Situation of Classroom Action Research-based Instruction}

The research results from the first objective revealed the current situation of classroom action research-based instruction of the Child Development Centre teachers. The data from the measurement form and interview found that most of the teachers specified the purposes of the research were to solve children's behaviour problems $(86.42 \%)$. Next, followed by to increase the development of children in terms of physical, emotional, mental, social and intellectual $(80.25 \%)$. Furthermore, to improve the teaching techniques for pre-school children $(38.27 \%)$. Nevertheless, some of them reported that to comply with the requirements and regulations in the teacher performance $(22.22 \%)$, as shown in Figure 4.

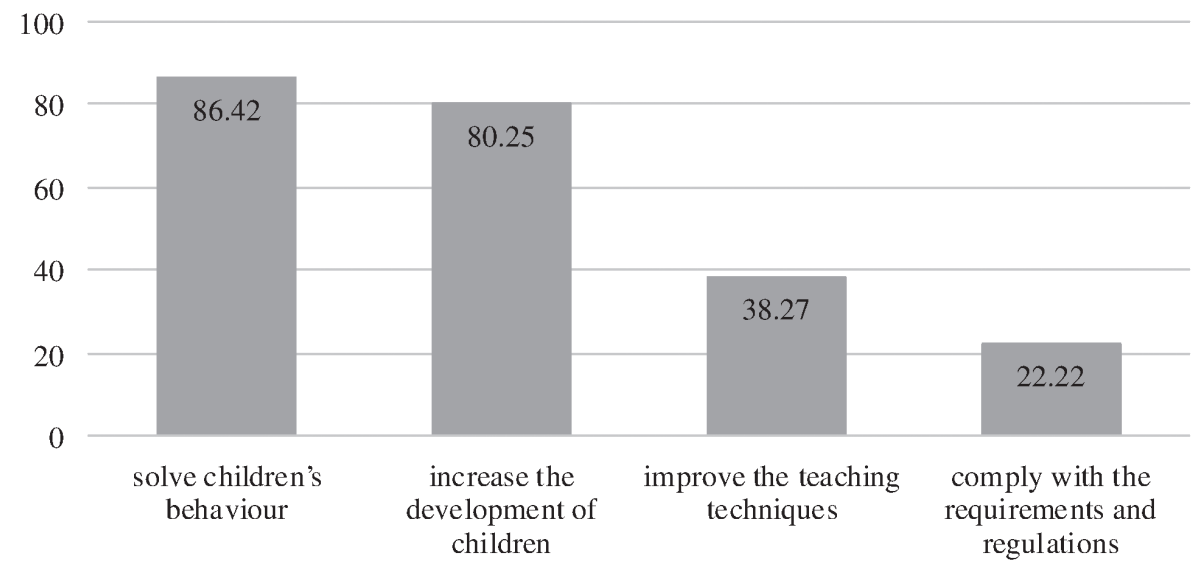

Figure 4. The percentage of the number of purposes to conduct research 
Most of the classroom action research conducted by both self-conducted research and collaboration with other teachers within the centre, and they usually utilised their research than others. Moreover, the result has shown that teachers conducted informal research, 1-2 pages report, rather than full report, five chapters, as shown in Figure 5.

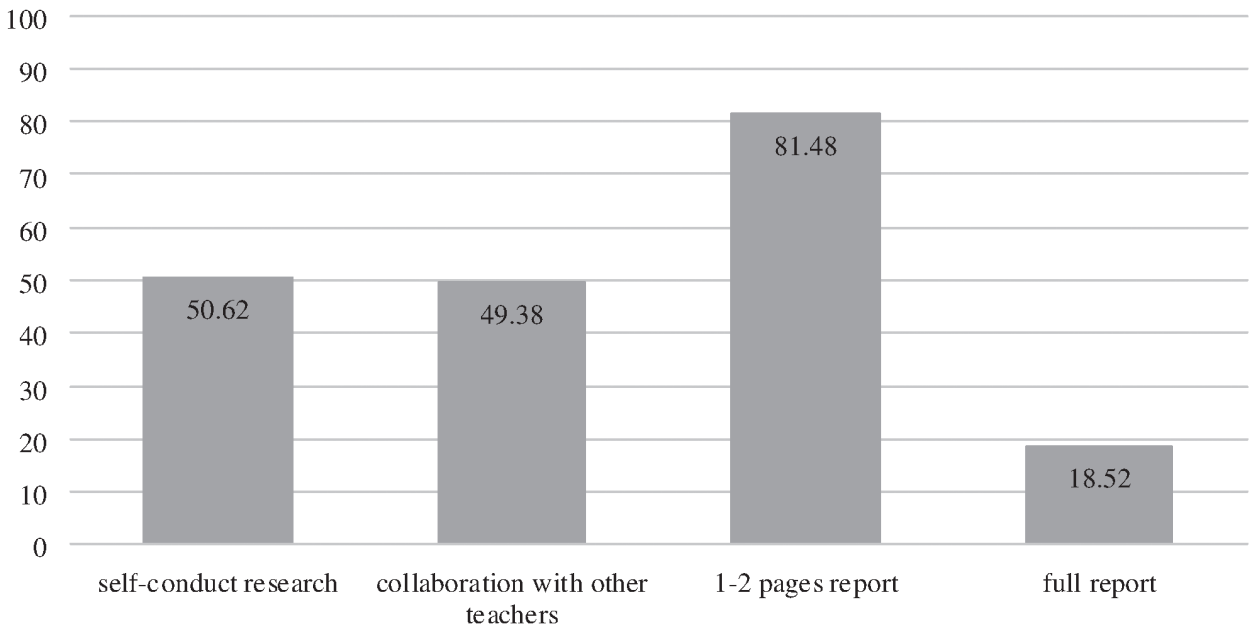

Figure 5. The percentage of the number of research collaboration and reporting

Teachers started the research process by determining what problems were occurring in their class that were problems affecting their teaching or student learning. Then, identified problems that occurred in the form of research problems and detailed research questions. Next, specified the research objectives, the research design, designated relevant persons, research facilities, and scheduled the work to be completed. The issues that teachers used to research were the problems that are important to the development of children. Regarding the interview, the teachers can determine the problems that occur in the class to define as the research objectives, able to control the research process and solve the problems by themselves, able to specify the relevant person, design the research method and data analysis method.

The teacher proceeded to solve the problems that occurred in the classroom using methods or innovations studied in accordance with the designed guidelines. Then, collecting data gathered from experimenting with innovations or methods to solve problems which occurred in the classroom by methods or innovations obtained from previous studies. However, there was a problem in collecting the data after trying to solve the problem or applying the innovation which was not yet complete. Teachers were able to report the results of data analysis to present the solutions. They were able to explain how a solution or innovation could be created or chosen to solve the problem. Furthermore, they were able to analyse and interpret the results clearly, both in the form of 1-2 pages report or full report.

The teacher presented the research results objectively, without bias, and almost all of them reflected the results during the research to all involved, including colleagues, administrators or parents. They delivered the research process and research results to consult, discuss, share knowledge and views with others by the opinions of relevant 
parties to improve and plan the next research process. Nevertheless, unfortunately, they would not share with the external expert.

The teachers could assess the success of problem-solving, whether it is effective or not, and how to proceed further to improved teaching by classroom action researchbased and classroom action research-based instruction. Furthermore, Teachers were able to find new methods or further research issues in the classroom research by constructing the use of the research process and the results of both themselves and others; however, the level was not much.

\section{Comparison of the Consequences of Classroom Action Research-based Instruction}

The results of the comparison of the consequences of classroom action researchbased instruction, the second objective, revealed that before receiving the experimental variables, the experimental group, 40 participants, had a mean score in learning management slightly higher than the control group with a mean score of 3.79 and the standard deviation was 0.59 , while the control group, 41 participants, had a mean score of learning management of 3.59, and the standard deviation was 0.64 . After that, the researchers tested the mean difference, starting with the variance between groups by testing the equality of variance with Levene's test $(\mathrm{F}=.085, \mathrm{p}=.772)$ showing that the variance of both groups had no difference. The researcher considered the t-test statistic and found that the value of $\mathrm{t}=.847(\mathrm{p}=.400)$ showed the average scores in learning management of both groups were not significantly different at the level of .05, as shown in Table 1.

Table 1

Comparison of Learning Management Consequences between Experimental and Control Groups before the Intervention

\begin{tabular}{lcccccc}
\hline \multirow{2}{*}{ Group } & $\mathrm{n}$ & $\mathrm{M}$ & $\mathrm{S}$ & \multicolumn{3}{c}{$\mathrm{t}$-test } \\
\cline { 5 - 8 } & & & & $\mathrm{t}$ & $\mathrm{p}$ \\
\hline Experiment & 40 & 3.79 & 0.59 & .847 & .400 \\
\hline Control & 41 & 3.59 & 0.64 & & \\
\hline
\end{tabular}

After receiving the experimental variables, it was found that the experimental group had a mean score of learning management more than the control group with a mean score of 3.82 and the standard deviation was 0.53 , which was slightly higher than before receiving the experimental variables, while the control group had a mean score of 3.56 and the standard deviation was 0.53 , slightly lower than before the experiment. The researcher considering the variance between groups by testing the equality by Levene's test $(\mathrm{F}=.007, \mathrm{p}=.933)$ showing that the variance in both groups had no difference. The researcher considered the t-test statistic and found that the value of $t=$ $2.134(\mathrm{p}=.036)$ showed the average scores of instructional managements of the two groups were different with statistical significance at the level of .05 . The result confirmed that the learning management outcomes of the experimental group were significantly higher than the control group at .05, as shown in Table 2. 
Table 2

Comparison of Learning Management Consequences between Experimental and Control Groups after the Intervention

\begin{tabular}{llllll}
\hline \multirow{2}{*}{ Group } & \multirow{2}{*}{$\mathrm{n}$} & $\mathrm{M}$ & $\mathrm{SD}$ & \multicolumn{2}{c}{$\mathrm{t}$-test } \\
\cline { 5 - 7 } & & & & $\mathrm{t}$ & $\mathrm{p}$ \\
\hline Experiment & 40 & 3.82 & 0.53 & 2.134 & $.036^{*}$ \\
\hline Control & 41 & 3.56 & 0.53 & & \\
\hline
\end{tabular}

* The mean difference is significant at the 0.05 level.

\section{Discussion}

The current situation of the Child Development Centre revealed that the purpose of classroom action research was to solve children's behaviour problems and to increase the development of children physically, emotionally, mentally, socially, and intellectually, however, have some reported that it is mandatory. Those are because classroom research is a requirement in the standard of operation of the child development centre of the local government organisation that aims to develop the process of learning activities or develop the behaviour of the children to achieve the specified quality (Royal Thai Government Gazette, 2017). In addition, classroom research is an integral part of teacher practice, which the Teachers Council of Thailand has established as a standard in teacher competency.

Similarly, Wongwanich (2017) and Gutierez and Kim (2018) refer that classroom action research must conduct by teachers in order to solve problems in the classroom and use it to improve teaching or to maximise the development of teacher and learners. That must be conducted quickly, and the results can be used immediately and reflect information about various operations in teachers' duties. Most of the research conducted in the classroom by teachers was informally conducted, 1-2 pages, and almost no collaboration with external scholars resulted in the research process has not been reflected. The teacher viewed that it was a formal ceremony and did not use the research results for real. Makovec (2018) studied that were is some teachers who were trained for educational activities, and very few published professional papers in the field of expertise they taught.

Moreover, the classroom action research needs ability and positive attitude to conduct (Gutierez \& Kim, 2018). Furthermore, teachers in school had overload with unnecessary things apart from teaching, which effects the main task. Hence, the teacher must complete everything by making it easy (Kukoja, 2019).

The research results from the interview revealed that the classroom action research of teachers had problem and obstacles. Even though the knowledge and skills of teachers are not enough to do research alone (Saral \& Reyhanlioglu, 2015; Meesuk, 2020), but they conduct research in the classroom alone. They have been developing themselves in the same way that they experienced as ever studied at the university. Tend to practice similar to what they had done (Makovec, 2018; Meesuk, 2020). The study of Petrovska et al. (2018) found that the differences in the view of teachers with different work experience had shown the importance of mentor teachers. Teachers in school need a colleague or mentor who shares knowledge, skills, and experiences into the teaching profession and school life. It is allowed to make sense of his pedagogical practices, which contributes to the enrichment of his / her professional skills. Because of the 
classroom action research-based instruction problems have been arising from the confusion in the teacher development process.

They were summarised by Meesuk, Sramoon and Wongrugsa (2019), Gutierez \& Kim (2018) who reported the problems in the teachers' research and teaching. First, the knowledge of the teachers obtained from the training is not enough to enable the teachers to conduct research by themselves, causing the teachers not to complete the research and become frustrated. Second, formal research requires a thorough review of relevant documents in order to provide a consistent framework for research and reasonable research design. However, the time constraint due to the daily workload of the teacher, therefore, makes the teacher unable to study the document thoroughly. Thirdly, due to the difficulty of completing the research, the teacher would stop researching only one matter. There is no incentive to conduct research continuously, resulting in no benefit to the development of teaching and learning in the classroom as it should be. Fourth, the research that teachers have taken is very time-consuming, resulting in the knowledge that cannot be used to solve problems in time and requires skills. It needs to be trained and learned by experts.

Nevertheless, most of the research training courses are intensive courses that study the principles of research, technical terms and processes used in research. Training methods were listening to lectures. However, in the real condition after the training, teachers do not have a mentor to conduct research, causing unable to conduct research successfully.

The results of the learning management comparison, the teachers using classroom action research-based instruction (experimental group) had a significantly higher mean score of learning management outcomes than teachers who provided regular teaching (control group) with statistical significance at the level of .05. It revealed that in the experimental group, the posttest scores were only slightly higher than before the experiment, but the control group decreased. Confirmed the learning management by classroom action research-based makes the results in learning management stable. Different from the control groups that do not use, that had been reduced until it makes a difference between the results of learning management over time. Because the characteristic of classroom action research-based instruction on the concepts of Kemmis and Mctaggart (2000) that emphasise the reflection of performance. The teacher can reflect the result of at every step of the operation. The reflection will retain the development of teachers, teaching methods, and solid knowledge. Make teachers ready to improve the method of action to be more appropriate and effective. Agree with Pharis, Wu, Sullivan, \& Moore (2019), which study about improving teacher quality and student achievement led to implementing research-based teacher effectiveness systems in Kentucky, USA. The results indicated the viewpoints concerning teachers' knowledge and understanding of teaching increased during the year. The student achievement identified student growth goals as needed. For teachers, they had gained knowledge and understanding of teaching and pedagogy by themselves research-based instruction (Sumaryanta, Mardapi, Sugiman, Herawan, 2019).

By referring to learning management by classroom action research-based makes the results in learning management stable, according to Maksimovic and Osmanovic (2019) that mentioned about the effective of reflection revealed the contemporary society has brought alter the vision of a teacher who no longer controls the teaching process but becomes an agent of critical change, accepting the role of a reflective practitioner. 
The reflection is beneficial for teachers since it enables them to acknowledge the experience, assume a critical attitude towards practice, enhance their awareness of teaching. Hence, the reflection which is an essential part of classroom action researchbased instruction (Wongwanich, 2017) making the development of teachers stable and more likely to progress.

Similar to the study of Impedovo and Ferreira-Meyers (2019) reported that acquiring new skills is challenging for all teachers and sustaining, it is also difficult. Teachers have to consider the implications in the classroom, in their community and relation to their professional career. The research-based teaching practices will be supported and exercised throughout the teachers' working life. Besides, as the study of Qvortrup (2019) also mentioned that the research-based teaching can improve teacher's professional but had the contradiction in the part of the effect on student achievement which Qvortrup stated that the effect on students' learning and development achievement still is not able to be indicated. This issue is argued by the latest study that mentioned about a researchbased approach can improve the capabilities of students in dealing with real life. Furthermore, it offers an effective, efficient learning strategy which is a crucial way of teaching, learning and professional development (Ratnawati \& Idris, 2020).

\section{Conclusions}

The results of the research can be summarised that most teachers conduct classroom action research to solve children's behaviour and increase children development in all aspects. The informal research 1-2 pages and almost no collaboration with external scholars are typically found. Problems and obstacles in classroom action research have been occurring until the present. After the sustainable teacher professional development strategy, classroom action research-based has implemented. The teachers using classroom action research-based instruction had a significantly higher learning management outcomes than teachers who provided regular teaching with statistical significance at the level of .05.

Moreover, teaching outcomes score is also stable. The teachers reported changes of their own. They want to develop and solve children's behaviour problems and develop their teaching techniques by using research to improve learning. They gain more ability to develop themselves without expert from outside by reflection, sharing, consulting about the research process to colleagues in the same school or group of people in the same profession. This process is the way of sustainable development related to school context to increase students and teacher outcomes, especially.

\section{Acknowledgements}

We would like to express our sincere gratitude to all Child Development Centre teachers of Department of Local Administration, Thailand, and Faculty of Technical Education, Rajamangala University of Technology for the in-kind supporting. Especially to the National Research Council of Thailand for the funds of this research.

\section{Conflict of interests}

The authors declare no conflict of interests. 


\section{References}

Akerson, V. L., Carter, I., Pongsanon, K., \& Nargund-Joshi, V. (2019). Teaching and learning nature of science in elementary classrooms: Research-based strategies for practical implementation. Science \& Education, 28(3-5), 391-411.

Bissonnette, J. D. \& Caprino, K. (2014). A call to action research: action research as an effective professional development model. Mid-Atlantic Education Review, 2(1), $11-22$.

Department of Local Administration. (2018). Early childhood education standards. Bangkok, Thailand: Ministry of Interior.

Fedosejeva, J., Boče, A., Romanova, M., Ivanova, O., \& Iliško, Dz. (2018). Education for sustainable development: The choice of pedagogical approaches and methods for the implementation of pedagogical tasks in the Anthropocene age. Journal of Teacher Education for Sustainability, 20(1), 157-179.

Giraud, F., \& Saulpic, O. (2019). Research-based teaching or teaching-based research: Analysis of a teaching content elaboration process. Qualitative Research in Accounting \& Management, 16(4), 563-588.

Gutierez, S. B., \& Kim, H. B. (2018). Peer coaching in a research-based teachers' professional learning method for lifelong learning: A perspective. Alberta Journal of Educational Research, 64(2), 214-221.

Heasly, B., Lindner, J., Iliško, Dz., \& Salìte, I. (2020). From initiatives, to insights, to implementation of the sustainability and securitability agenda for 2030. Discourse and Communication for Sustainable Education, 11(1), 1-4.

Impedovo, M. A., \& Ferreira-Meyers, K. (2019). Expanding use of research-based teaching practices after an international master course. Transformative Dialogues: Teaching \& Learning Journal, 12(1), 1-13.

Kemmis, K., \& McTaggart, R. (2000). Participatory action research. Handbook of qualitative research. London: SAGE.

Kukoja, K. (2019). The effect of early childhood education and care services in Latvia. Journal of Teacher Education for Sustainability, 21(2), 17-26.

Makovec, D. (2018). The teacher's role and professional development. International Journal of Cognitive Research in Science, Engineering and Education, 6(2), 33-45.

Maksimovic, J., \& Osmanovic, J. (2019). Perspective of cognitive thinking and reflective teaching practice. International Journal of Cognitive Research in Science, Engineering and Education, 7(2), 1-10.

Meesuk, P. (2020). Research for learning development for vocational teacher. Pathumthani, Thailand: Rajamangala University of Technology Thanyaburi.

Meesuk, P. (2016). Educational research. Bangkok, Thailand: Triple Education.

Meesuk, P., Sramoon, B., \& Wongrugsa, A. (2019). A development of learning management by using classroom action research-based instruction innovation for potential enhancing of researcher-teacher and children in Thailand early childhood development centre. Pathumthani, Thailand: Rajamangala University of Technology Thanyaburi.

Mirke, E., Cakula, S., \& Tzivian, L. (2019). Measuring teacher-as-learners' digital skills and readiness to study online for successful e-learning experiences, 21(2), 5-16. doi: 10.2478/jtes-2019-0013 
Munkong, N. (2019). The study of problems and educational management guidelines of the child development centre of Bang Pla Sub-district Administration Organisation, Bang Phli District, Samut Prakarn Province. Bangkok, Thailand: Dhonburi Rajabhat University.

Petrovska, S., Sivevska, D., Popeska, B., \& Runcheva, J. (2018). Mentoring in teaching profession. International Journal of Cognitive Research in Science, Engineering and Education, 6(2), 47-56.

Pharis, T. J., Wu, E., Sullivan, S., \& Moore, L. S. (2019). Improving teacher quality: Professional development implication from teacher professional growth and effectiveness system implementation in rural Kentucky high school. Educational Research, Quarterly, 42(3), 29-48.

Pipere, A., Veisson, M., \& Salite, I. (2015). Developing research in teacher education for sustainability: UN DESD via the Journal of Teacher Education for Sustainability. Journal of Teacher Education for Sustainability, 17(2), 5-43.

Pookeit, L. (2009). Project-based \& research-based instruction. Bangkok, Thailand: Saha and Son.

Qvortrup, L. (2019). Provision of school data and research based teacher professional development: Does it work? Data- and research-informed development of schools in the Danish “program for learning leadership”. Education Sciences, 9(2), 1-12.

Ratnawati, N., \& Idris. (2020). Improving student capability through research-based learning innovation in e-learning system. International Journal of Emerging Technologies in Learning, 15(4), 195-205.

Royal Thai Government Gazette. (2017). Constitution of the Kingdom of Thailand B.E. 2560. Bangkok, Thailand: Author.

Rutherford, D. J., \& Lovorn, C. (2018). Research-based program development: Refining the service model for a geographic alliance. Journal of Geography, 117(2), 88-98.

Saral, D. G., \& Reyhanlioglu, D. (2015). An analysis of educational faculty students' research self-efficacy in term of a number of variables. Social and Behavioral Sciences, 174, 1138-1145.

Sumaryanta, Mardapi, S., Sugiman, Herawan, T. (2019). Community-based teacher training: Transformation of sustainable teacher empowerment strategy in Indonesia. Journal of Teacher Education for Sustainability, 21(1), 48-66.

Wongwanich, s. (2017). Classroom action research. Thailand, Bangkok: Chulalongkorn Press.

Correspondence concerning this paper should be addressed to Parinya Meesuk, PhD, Assistant Professor, Rajamangala University of Technology Thanyaburi, 39 M. 1 Rangsit-Nakornnayok Rd., Klong 6, Thanyaburi, Pathumthani, Thailand. Email: parinya_m@rmutt.ac.th 